\title{
Madre sólo hay una. Ilustración, maternidad y medicina en el Perú del siglo XVIII
}

\author{
Claudia Rosas Lauro \\ Pontificia Universidad Católica del Perú- \\ Instituto de Estudios Humanísticos, Universidad de Florencia
}

Este trabajo estudia cómo a fines del siglo XVIII en el Perú se dio la construcción de un modelo de madre, que sería el eje en torno al cual debía girar la familia ilustrada. A través del análisis de la prensa y otros escritos de la época, se muestra cómo el discurso higienista sobre el embarazo y el parto, la polémica sobre la lactancia materna y la diatriba de las parteras frente al saber científico del médico, entre otros aspectos, van configurando una nueva visión de la maternidad. Esta, a su vez, se vincula con procesos más complejos que involucraban a la sociedad en su conjunto como son la emergencia de un periodismo moderno y una opinión pública o la tentativa de formalizar el saber científico con el acrecentamiento del rol social del médico. De esta manera, se muestra una de las múltiples caras que asume el difícil proceso de construcción de la modernidad.

PALABRAs Clave: Maternidad, Ilustración, Historia de la mujer, Historia de la medicina.

This work studies the construction of a model of maternity that served as the base of the enlightenment family in the late 18th century of Peru. It analyzes journalism and other texts of the period, to show the hygienist discourse about pregnancy and birth, the controversies about breast-feeding, the diatribes against midewifes versus scientific knowledge of medical doctors, among other aspects, to configure a new vision of maternity. This vision relates to a more complex process of society on the whole, such as the birth of a modern journalism and public opinion or the formalization of scientific knowledge and the increased social role of medical doctor. In this way, this discourse shows one of the many faces of the difficult process of modernity.

KEYwords: Maternity, Enlightenment, Women's History, History of medicine.

"Las que custodian en su vientre el sagrado fruto que va a perpetuar la especie humana, y añadir nuevo ser a la Naturaleza, no tienen menos obligación en impedir su inminente pérdida, que en poner obstáculo a los medios que la facilitan". ${ }^{1}$

Con estas palabras, el autor de la "Disertación Primera en la que se proponen las reglas que deben observar las Mugeres en el tiempo de la pre-

1 Suadel, Erasistrato: "Disertación Primera en la que se proponen las reglas que deben observar las Mugeres en el tiempo de la preñez”, 5 de junio de 1791, Mercurio Peruano, II, Edición facsimilar Biblioteca Nacional del Perú, Lima, 1964, págs. 88-95. 
ñez", publicada en el Mercurio Peruano el 5 de junio de 1791, advertía sobre la importancia de la higiene y la salud durante el embarazo y el parto. Como éste, muchos testimonios nos permitirán reconstruir y analizar el discurso sobre la maternidad que los ilustrados, médicos y demás hombres de ciencia proyectaron a la sociedad, con fines pedagógicos y docentes, a través de textos escritos principalmente en periódicos. ${ }^{2}$

El tema, olvidado por mucho tiempo por la historiografía, ${ }^{3}$ nos lleva a tratar aspectos vinculados con la medicina, el cuerpo y el género que en los estudios sobre las Reformas Borbónicas y la Ilustración en el Perú no han concitado mayormente el interés de los investigadores. La relevancia del tema reside en que la maternidad, además de ser una temática de estudio de importancia en sí misma, refleja el entrecruzamiento de procesos más complejos que se dieron a nivel del país a fines del siglo XVIII e inicios del XIX. En este sentido, el tema de la maternidad se convierte en una de las muchas ventanas desde la cual podemos auscultar la sociedad peruana de las postrimerías de la época colonial. En este período, la Ilustración con su nueva visión del mundo no dejó de contemplar el tema de las mujeres, a quienes tenía reservado un papel protagónico en la construcción de la nueva sociedad. Las ideas ilustradas se difundieron en un Perú que estaba viviendo los efectos del reformismo borbónico que, como proyecto modernizador, buscaba cambiar la sociedad. Sin embargo, el proyecto borbónico en el Perú presentó contradicciones y ambivalencias tanto de parte de la Corona como de las clases altas limeñas y, como señala Charles Walker, lo que se plasmó en la realidad fue una ilustración "a medias". Si bien hubo un esfuerzo por "secularizar" y pasar al Estado el control no sólo del espacio público, sino también, del privado, fue un esfuerzo a medias. La Corona

2 Agradezco a Scarlett O’Phelan y a Sara Beatriz Guardia la invitación que me dirigieron en ocasiones distintas para participar en coloquios internacionales sobre el tema, que fueron importantes espacios donde exponer y discutir los avances de esta investigación, en cuya versión final fueron valiosos los comentarios de Charles Walker y José Ragas. Quiero dedicar el trabajo, haciendo honor al modelo de feminidad caracterizado por la sensibilidad, a mi madre y a mis abuelas, distintos modelos de mujer y de madre.

3 Las primeras aproximaciones al tema se encuentran en Rosas, Claudia: "Jaque a la Dama. La mujer en la prensa limeña de fines del siglo XVIII", en Zegarra, Margarita (Ed.) Mujer y Género en la historia del Perú, Cendoc-Mujer, Lima, 1999, págs. 143-171. y Rosas, Claudia: "Educando al bello sexo. La mujer en el discurso ilustrado", en O'Phelan, Scarlett (Comp.) El Perú en el siglo XVIII. La Era Borbónica, IRA-PUCP, Lima, 1999, págs. 369-413. Es importante también Zegarra, Margarita: "La construcción de la madre y de la familia sentimental. Una visión del tema a través del Mercurio Peruano", Histórica, XXV-1, Lima, 2001, págs. 161-207. Para el siglo XX es relevante el libro de Mannarelli, María Emma: Limpias y modernas. Género, higiene y cultura en la Lima del Novecientos, Flora Tristán, Lima, 2000. 
se mostró preocupada por algunos de los nuevos aires científicos y, a su vez, las clases altas vieron con inquietud el nuevo poder que iba adquiriendo el Estado.

El nuevo discurso sobre la feminidad se vio impulsado por el desarrollo y los grandes avances verificados en el campo de la ciencia y la medicina durante la centuria, que tuvieron como consecuencia el crecimiento de la importancia del papel social del médico y la conversión de la medicina en un discurso normativo público dirigido también a las mujeres. De esta manera se estaban sentando las bases para la construcción de la sociedad burguesa del siglo XIX, en la que la mujer tendría una función importante en el ámbito doméstico y, sobre todo, en su rol de madre. Este proceso iba de la mano con la paulatina diferenciación entre los espacios público y privado; este último, circunscrito al hogar y la familia, será en consecuencia el espacio por excelencia de la mujer. Para lograr tal fin, había que educarla en su nuevo papel dentro de la sociedad y los periódicos van a cumplir una función principal para la difusión de estos contenidos, pues la ilustración puso de relieve su función pedagógica orientada a la reforma de las costumbres.

El artículo explora diversos aspectos vinculados con una esfera vital de la condición femenina, la maternidad, que es muy importante para la configuración de una moderna sociedad en el siglo XIX. Un primer aspecto que se descubre en el discurso dieciochesco es la relevancia del embarazo, concebido como un estado en el que se le deben prodigar a la madre los mayores cuidados para prevenir el aborto. Para cumplir tal fin, surgen a cada momento los preceptos higienistas que se deben seguir durante la gestación y el parto, desplegados por médicos y demás hombres de ciencia, quienes se preocupan también por el tema del aumento de la población. Al lado de estas preocupaciones, se encuentran los estudios sobre la naturaleza de la influencia de la madre sobre el feto y la discusión sobre los antojos de las embarazadas, que manifiestan el interés por el progreso de la naturaleza humana.

Un segundo punto a tratar se refiere al parto, momento culminante de la gestación. A este respecto, los ilustrados aconsejan acerca de la manera en que deben efectuarse, presentan sesudas disquisiciones sobre las formas de dar a luz y cuestionan severamente la labor de las parteras y comadronas, exponiendo los principios racionalistas de la moderna obstetricia. El tercer aspecto abarca un tema de gran importancia para ilustrados y médicos, el cuidado del bebé, donde se puede entrever una concepción de la 
maternidad y del amor maternal que prefiguran la moderna familia ilustrada o "sentimental". Asimismo, encontramos en los textos un énfasis en propagandizar los beneficios que traía la lactancia materna y los perjuicios que acarreaba el recurrir a las amas de leche, que generalmente eran negras y mulatas de baja condición social. Para los intelectuales ilustrados y médicos del siglo XVIII la maternidad tenía una gran relevancia para la configuración de la nueva sociedad, por eso para ellos, madre sólo hay una.

\section{Ilustración, periodismo y medicina en el siglo XVIII}

En la Lima del Siglo de las Luces, hombres de ciencia escribieron sobre las mujeres, discutieron sobre su naturaleza misteriosa, se refirieron a sus cuerpos, reflexionaron sobre el papel que debían cumplir en la sociedad; en fin, intentaron abordar en sus escritos hasta los aspectos más íntimos del ser femenino, desde un punto de vista masculino y a partir de una visión ilustrada del mundo. ${ }^{4} \mathrm{Si}$ bien con respecto a la mujer podemos hablar desde el presente de una "Ilustración olvidada", ${ }^{5}$ en esta época ella terminó siendo el centro de las preocupaciones de médicos, intelectuales y sacerdotes quienes, bajo los preceptos ilustrados, fueron definiendo de una manera nueva su ubicación y su papel en la moderna sociedad que buscaban forjar. Con ello colaboraron, aunque todavía atados a viejas creencias, el desarrollo científico y los grandes avances del conocimiento médico de la época que vieron en la higiene la forma más adecuada para prevenir las enfermedades y lograr la salud pública y, a su vez, dieron gran relevancia al rol del médico en la sociedad al convertir a la medicina en un discurso normativo público dirigido también a las mujeres. Este discurso de carácter laico, poco a poco, desplazó al tradicional discurso religioso por el

4 La Ilustración puede ser enfocada no sólo como un discurso, sino también como una mentalidad. Véase los trabajos sobre la Ilustración española de Sánchez-Blanco, Francisco: La mentalidad ilustrada, Taurus, Madrid, 1999. Sánchez-Blanco: Europa y el pensamiento español del siglo XVIII, Alianza, Madrid, 1991. También los clásicos de Sarrailh, Jean: La España ilustrada de la segunda mitad del siglo XVIII, FCE, México, 1992. y Heerr, Richard: España y la Revolución del siglo XVIII, Aguilar, Madrid, 1979.

$5 \mathrm{Si}$ bien los ilustrados peruanos no llegaron a formular un discurso revolucionario sobre la condición femenina y, en muchos casos, estuvieron al margen de las polémicas más importantes de su tiempo que se desataron sobre todo a raíz de la Revolución Francesa de 1789, muchas de estas propuestas, como las de Condorcet o los Derechos de la Mujer y la Ciudadana, ni siquiera prosperaron en Europa. Puleo, Alicia (Editora): La Ilustración olvidada. La polémica de los sexos en el siglo XVIII: Anthropos, Madrid, 1996. 
avance de un lento proceso de secularización a través del cual la Iglesia fue abandonando paulatinamente su rol de control sobre la sociedad que pasó a ser asumido cada vez más con mayor fuerza por el Estado. Entonces, las normativas sociales que antes eran lanzadas por los religiosos desde el púlpito, en adelante serán sancionadas también por los hombres de ciencia y, en particular, los médicos que con su discurso higienista tendrán una participación cada vez mayor en los asuntos de interés público. Estos cambios respondían a lo que Norbert Elías ha llamado el proceso civilizatorio, a través del cual se dio una domesticación de los impulsos físicos y emocionales del ser humano así como una privatización de las funciones del cuerpo ${ }^{6}$ en la cual los médicos cumplirán un papel importante.

Todo ello se vio influido por el impacto de las Reformas Borbónicas, programa modernizador del Imperio español impulsado por la Corona bajo las ideas de la Ilustración. Las medidas de reforma no sólo se limitaron al terreno económico o político, sino que también pretendieron abarcar los diferentes aspectos que integraban la realidad colonial en su conjunto. ${ }^{7}$ Por ello, no estuvieron ausentes las propuestas de carácter cultural, que involucraban a la familia y, por ende, a la mujer. El siglo XVIII fue un período importante de gestación de discursos e imágenes de la sociedad peruana, que intentarán plasmarse en la realidad a lo largo del siglo siguiente; pero, que quedarán truncos por el período de profunda inestabilidad que signó al país luego de las guerras de Independencia. Sin embargo, muchas de las ideas formuladas en esta época, fueron retomadas cuando el Estado republicano logró consolidarse, de tal suerte que los modernizadores de fines del siglo XIX serán herederos de los ilustrados. ${ }^{8}$ En el caso de la maternidad, será a inicios del XX cuando se lleven a la práctica muchas de estas ideas. ${ }^{9}$

Esto no significó, como señala Scarlett O'Phelan, un fracaso categórico del proyecto borbónico, pues en una serie de ámbitos se logró concre-

6 Elías, Norbert: El proceso de la civilización. Investigaciones sociogenéticas y psicogenéticas, FCE, México, 1987.

7 Recientes estudios abordan el impacto de las Reformas Borbónicas en los diferentes ámbitos de la sociedad colonial, que incluyen aspectos culturales. Véase O’Phelan (Comp.): El Perú en el siglo XVIII... págs. 7-12.

8 O’Phelan, Scarlett: "Introducción”, en O’Phelan (Comp.): El Perú en el siglo XVIII...

9 El discurso sobre la maternidad difundido en el siglo XVIII fue retomado a fines del XIX e inicios del XX, en que la preocupación por la alta tasa de mortalidad infantil, la difusión de ideas higienistas por los médicos, la campaña a favor de la lactancia materna, se dieron en el contexto de un Estado más sólido que buscó la modernización y homogeneización de la sociedad. Mannarelli: Limpias y modernas... 
tar las esperadas reformas. Una cosa era la teoría y otra muy distinta la práctica, dado que por un lado la población no estaba preparada para asimilarlas y, por otra parte, la élite no estuvo dispuesta a asumir ciertas ideas ilustradas en una sociedad de carácter colonial y en la cual el Estado estaba incrementando cada vez más su poder. A ello se sumaba lo subrayado por la misma autora: el problema de los recursos económicos que demandaban las medidas y que, en términos prácticos, hicieron viables unas e inviables otras. No se debe olvidar el peso de la Iglesia y el catolicismo en la ilustración española y, a su vez, en la peruana, que alimentó las ambigüedades y contradiccones en la aplicación de los ideales ilustrados. ${ }^{10}$ En este ámbito, se impulsó una Ilustración católica y pragmática destinada a fortalecer el poder estatal, que estableció una alianza con las elites para llevar adelante el programa de reformas. El objetivo era lograr el sometimiento de la Iglesia al Estado y la puesta en práctica del regalismo se inició durante el gobierno del virrey Manuel de Amat y Juniet (1761-1776) con la expulsión de los jesuitas, la imposición del patronazgo real a la Iglesia y la Inquisición, la secularización del clero y la posibilidad de leer libros antes prohibidos. Según Víctor Peralta una nueva fase de ese proceso se inició a fines de siglo, durante el gobierno de Gil de Taboada. A esta etapa corresponde el Mercurio Peruano, periódico en el que no sólo participó el clero sino también la elite criolla y donde se trató de conjugar fe y razón. La cultura bíblica, la crítica modernista a las formas de devoción y religiosidad popular así como la reconciliación entre escolasticismo e iluminismo fueron rasgos de la publicación. Asimismo, el rechazo de los filósofos europeos, en especial Voltaire, y la posición contraria al ateísmo, el deísmo y el enciclopedismo impidieron la asimilación de muchos de los contenidos de la Ilustración europea.

De esta manera, se estaban echando fatigosamente los cimientos para la construcción de la sociedad burguesa del siglo XIX, con su diferenciación entre espacio público y privado. El primero, destinado a la política y los negocios públicos, campo de acción netamente masculino; y el segundo, orientado hacia el hogar y la familia y, en consecuencia, espacio de las mujeres. En el logro de este cometido, los periódicos tuvieron un papel importante, pues debían ser los medios de difusión de las nuevas ideas y el saber actualizado en todos los campos. En estos periódicos se trataban

10 Consúltese Peralta, Víctor: "Las razones de la fe. La Iglesia y la Ilustración en el Perú, 1750-1800”, en O’Phelan (Comp.): El Perú en el siglo XVIII..., págs. 177-204. 
temas referidos a la salud y la higiene con el fin de que estos conocimientos constituyesen un saber útil para mujeres y madres. Si bien es cierto que estos contenidos eran destinados principalmente a las mujeres de las clases acomodadas, hay que considerar que esta ilustración no era privativa de las elites, sino que también se difundió a otros grupos de la sociedad colonial a través de diversas vías de trasmisión, que permitieron la apropiación de este discurso por parte de las clases populares. ${ }^{11}$

En el seno de ese lento proceso de distinción de espacios se fue configurando la opinión pública, ${ }^{12}$ alimentada por el desarrollo de un periodismo de carácter moderno ${ }^{13}$ que, en la Lima de fines del siglo XVIII, se manifestó a través de la presencia de cuatro publicaciones periódicas. La de menor duración fue el Semanario Crítico, que —editado en 1791 por el sacerdote franciscano Juan Antonio Olavarrieta— llegó a tener tan solo dieciséis números hasta que se interrumpió su publicación. ${ }^{14} \mathrm{Si}$ bien tuvo como intención inicial la crítica de costumbres en general, terminó dedicándose principalmente al tema de la crianza y educación de los hijos por lo que se trataba del primer periódico destinado a las mujeres, esencialmente a las madres de la élite. De mayor duración fue el Diario de Lima que, bajo la dirección de Francisco Antonio Cabello y Mesa - conocido como Jaime Bausate y Mesa—, se publicó entre 1790 y 1792, abocándose a temas diversos..$^{15}$ De diferente naturaleza fue la Gaceta de Lima de 1793,

11 Véase Estenssoro, Juan Carlos: "La plebe ilustrada: el pueblo en las fronteras de la razón", en Walker, Charles (Comp.): Entre la retórica y la insurgencia: las ideas y los movimientos sociales en los Andes, Siglo XVIII, CBC, Cuzco, 1996, págs. 33-66.

12 Sobre el tema de la opinión pública consúltese el trabajo clásico de Habermas, Jurgen: Historia y crítica de la opinión pública, Gustavo Gilli, Barcelona, 1981 y los estudios más recientes de Chartier, Roger: Espacio público, crítica y desacralización en el siglo XVIII, Gedisa, Barcelona, 1995; Furet, François y Ozouf, Mona: Dizionario Crítico della Rivoluzione Francese, Bompiani, Milán, 1994, págs. 907-107; Baker, Keith Michael: Inventing the French Revolution, Cambridge University Press, Nueva York, 1994, págs. 167-199.

13 Para América hispánica consultar Guerra, François-Xavier: Modernidad e Independencias. Ensayos sobre las revoluciones hispánicas, Mapfre-FCE, México, 1993. Para el caso peruano véase Macera, Pablo: "El periodismo en la Independencia", en Trabajos de Historia, t. II, INC, Lima, 1977, págs. 325-342 y Peralta, Víctor: "La revolución silenciada. Hábitos de lectura y pedagogía política en el Perú, 1790-1814”, Anuario de Estudios Americanos, LIV-1, 1997, págs. 107-134.

14 Sobre este periódico son importantes los estudios de Dunbar Temple, Ella: Periodismo peruano del siglo XVIII. El Semanario Crítico, Ed. Lumen, Lima, 194?, y Forns, Roberto: "La Estrategia Comunicativa del Semanario Crítico de Juan Antonio Olavarrieta. Ilustración y polémica en el periodismo limeño de 1791”. Tesis (Bach.) Pontificia Universidad Católica del Perú, Lima, 1988.

15 Para información sobre su editor y un estudio del periódico véase Martini, Mónica: Francisco Antonio Cabello y Mesa, un publicista ilustrado de dos mundos (1786-1829), Instituto de Investigaciones sobre Identidad Cultural, Universidad del Salvador, Buenos Aires, 1998. 
cuyo objetivo fue dar la versión oficial de la Revolución Francesa, convirtiéndose en el primer periódico de carácter internacional dedicado exclusivamente a informar sobre el hecho político más significativo del momento. ${ }^{16}$ De todos ellos, el más destacado fue el Mercurio Peruano, periódico editado por la Sociedad de Amantes del País que circuló desde 1791 hasta 1795, contando con el auspicio de las altas autoridades coloniales, incluso del virrey Gil de Taboada y Lemos, quien le dedicó unas líneas favorables en su Memoria de Gobierno. ${ }^{17}$ En su publicación estuvieron comprometidos miembros de la elite intelectual como Hipólito Unanue, José Baquíjano y Carrillo, entre otros destacados personajes, que escribieron sendas páginas sobre temas orientados al conocimiento de los diversos aspectos que integraban la realidad del país, exaltando sus cualidades y refutando las críticas que se le hacían desde Europa. En este sentido, el Mercurio era expresión de un nacionalismo criollo, cuyas raíces se hundían en los siglos XVI y, sobretodo, XVII. ${ }^{18}$ En cada uno de los periódicos se puede vislumbrar un discurso sobre la mujer.

La circulación de estas publicaciones periódicas tenía cierta amplitud, ${ }^{19}$ y si bien se daba principalmente, entre los grupos de poder de la sociedad colonial, los sectores populares urbanos no estuvieron al margen de los contenidos que difundían, pues los periódicos eran leídos y comentados en los diferentes espacios de sociabilidad ${ }^{20}$ de la ciudad como los cafés, las fondas, las barberías y otros lugares públicos. Entonces, prácticas sociales como la lectura pública y en voz alta permitió a la población anal-

16 Para un análisis del periódico Rosas, Claudia: "La Imagen de la Revolución Francesa en el Virreinato Peruano a fines del siglo XVIII", Tesis (Lic.) Pontificia Universidad Católica del Perú, Lima, 1997.

17 Un estudio fundamental sobre esta publicación periódica lo ofrece Clément, Jean-Pierre: $E l$ Mercurio Peruano, 1790-1795, Vol. I, Iberoamericana-Vervuert, Madrid-Frankfurt, 1997.

18 Brading, David: Orbe Indiano. De la monarquía católica a la república criolla, 1492-1867, FCE, México, 1991. y Lavallé, Bernard: Promesas ambiguas. Ensayos sobre criollismo colonial en los Andes, IRA, Lima, 1993.

19 Sobre la difusión de los periódicos, sabemos que la del Mercurio era muy buena en Lima porque un poco más de la mitad de los suscriptores pertenecían a la capital del Virreinato. También circuló en las provincias y a partir de 1794, se pudo adquirir en la tienda de Joseph Calvo, en la Calle de Bodegones frente al Café del mismo nombre, que era el más concurrido de la época. En esa misma calle se vendía el Semanario, mientras que la Gaceta se debía comprar directamente en la librería de Guillermo del Río, ubicada en la calle del Arzobispo. Los suscriptores del Diario recibían el periódico todos los días en su casa y a los que residían en provincias les llegaba a través del correo.Véase Medina, Toribio: La Imprenta en Lima, t. III, Santiago de Chile, 1905.

20 Sobre la noción de sociabilidad véase Agulhon, Maurice: "La sociabilidad como categoría histórica”, en Formas de sociabilidad en Chile 1840-1940, Fundación Mario Góngora, Santiago de Chile, 1992, págs. 1-10. 
fabeta el acceso a la información periodística y, en general, a la palabra escrita. ${ }^{21}$ Las mujeres habrían participado de estas formas de sociabilidad y de difusión de la información..$^{22}$ Además de los pocos casos que conocemos de suscriptoras a los periódicos, muchas de ellas habrían tenido acceso a los escritos a través de sus maridos dada la estructura jerárquica y patriarcal de las familias. Tanto es así que los ilustrados impulsaron, aunque tímidamente, la educación femenina, advirtiendo de "...los daños horrorosos que, especialmente en el bello sexo, acarrea su ignorancia"; ${ }^{23}$ pero, ilustración femenina siempre y cuando se dirigiera a cumplir a cabalidad el nuevo rol establecido en el ámbito familiar. Justamente la Ilustración dirigió su discurso a la mujer porque la consideraba piedra angular en la construcción de un nuevo tipo de familia y de sociedad. El periodismo aparece así como una tribuna moral laica cumpliendo una función pedagógica y docente dirigida al sector femenino.

\section{El discurso higienista y la pedagogía de la madre ilustrada}

La maternidad cobró gran relevancia en el entramado de ideas que dieron forma a la nueva imagen de mujer dentro del discurso ilustrado. El ser de la mujer estaba dirigido al matrimonio y, dentro de ese marco, se debía dar, naturalmente, la procreación, que era el fin al que estaba destinada toda mujer. Pero la maternidad no estaba exenta de graves problemas que se trataron de solucionar a través de un discurso prescriptivo establecido por el médico, poseedor del saber científico necesario a tal fin y guiado por los principios de la higiene. Sin embargo, los tratados médicos durante la época moderna expresaron una visión negativa del sexo femenino, ${ }^{24}$ cuyas raíces se remontaban a la Antigüedad.

Desde siempre se había planteado la inquietud sobre el dimorfismo sexual y su respuesta se había dado de acuerdo con la cultura y la mentali-

21 En Europa la lectura en voz alta fue una práctica común para apropiarse del texto escrito como demuestra Chartier, Roger: Libros, lecturas y lectores en la Europa Moderna, Alianza, Madrid, 1993.

22 Zegarra, Margarita: "El honesto velo de nuestro sexo. Sociabilidad y género en mujeres de sectores populares en la Lima del 800”, en Zegarra (Ed.): Mujeres y género..., págs. 183-204.

23 Bausate y Mesa, Jaime [Cabello y Mesa, Francisco Antonio] (Editor): Diario de Lima, 20 de abril de 1791.

24 Un estudio pionero sobre la visión de la mujer en el siglo XVIII se encuentra en Macera, Pablo: "Sexo y coloniaje", en Trabajos de Historia, t. III, INC, Lima, 1974, págs. 297-352. 
dad de la época. La teoría de los humores, heredada de la Antigüedad, y los principios de la fisiología galénica atravesaron todo el Medioevo para explicar de modo convincente el dimorfismo sexual, tal es así que permanecieron como el fundamento del pensamiento médico hasta entrado el siglo XVII y aún después. Se instauró entonces una imagen de la mujer como ser imperfecto, de humor frío y húmedo y de cuerpo débil e impotente. Asimismo, heredera de la imagen aristotélica de la mujer, la medicina ve obstaculizado su desarrollo. El cuerpo femenino se ve en función del masculino, sin poder independizarse de él; por eso será definido como incompleto y defectuoso.

En los periódicos peruanos del siglo XVIII encontramos autores que abordaron este tema estableciendo una clara diferenciación de los sexos a diversos niveles desde lo biológico y físico a lo cultural. El primero será justamente la premisa del segundo, pues dentro del discurso ilustrado se recurre al modelo de la naturaleza para justificar el estado de cosas en lo social. Así mientras en una disertación sobre si una mujer podía convertirse en hombre, se precisaban las diferencias físicas entre los sexos, ${ }^{25}$ en otros artículos se establecía una nítida diferenciación entre los comportamientos, costumbres y usos femeninos y masculinos. ${ }^{26}$ Todavía estos escritos estaban impregnados de las ideas de Galeno, Hipócrates o Aristóteles. ${ }^{27}$ La larga duración de estos presupuestos no sólo se dio porque explicaban satisfactoriamente la anatomía femenina, sino también porque implicaban una de las características de la fisiología femenina: el no funcionamiento. Hay que esperar al ilustre obstetra François Mauriceau — tan citado por los intelectuales peruanos - para encontrar una explicación libre de este apriori negativo.

En el del siglo XVI se desató una acalorada polémica, a través de la cual la mujer encontró una nueva identidad; a partir de entonces ya no será vista solamente como una copia defectuosa del hombre, sino como un cuer-

25 Ganarrilla, Joseph Torpas [Larrinaga, Joseph Pastor de]: "Disertación en que se trata si una muger se puede convertir en hombre", 9 y 12 de agosto de 1792, Mercurio Peruano, t. V, págs. 230243.

26 En una noticia de la Gaceta N. ${ }^{\circ} 22$ del 11 de junio de 1794 se ve a las revolucionarias que vestían pantalones como los sans-cullottes, hecho que evidenciaba la total inversión del orden natural y social provocado por la Revolución Francesa. Durand, José (Editor): La Gazeta de Lima. De 1793 a Junio de 1794. Gil de Taboada y Lemos, Cofide, Lima, 1983, pág. 298.

27 Un ejemplo de cómo era visto el cuerpo femenino por la ciencia médica de la época y la vigencia de los presupuestos de la Antigüedad se encuentra en Cosamalón, Jesús: "Una visión del cuerpo femenino y de la enfermedad a partir de dos diagnósticos médicos, Lima 1803”, Anuario de Estudios Americanos, LX-1, Sevilla, 2003, págs. 109-138. 
po completo y singular. Sin embargo, por esa independencia de lo masculino tuvo que pagar un alto precio: convertirse en prisionera de su propio cuerpo, más aún, de una parte de su cuerpo, el útero. Así, se pasó del mito de la mujer incompleta al mito de la mujer útero. La mujer será condenada a ser definida por el órgano dominante y tiránico que habita en ella, ejerciendo su dominio sobre la totalidad de su ser. El útero, sede de la fecundación y de la gestación, simboliza a la mujer misma. Por eso recibe el nombre de matriz o madre, porque la mujer existe en relación a este órgano. Entonces, se instaura una teoría que distingue la identidad femenina en base a su diferencia. Antes la teoría de los humores servía para justificar una visión de la naturaleza femenina frágil e inestable; en adelante será la irascibilidad del útero, que sustituye al temperamento húmedo, la que explique la inferioridad natural de la mujer. Por ello, los médicos se esforzarán por explicar la especificidad del órgano que define a la mujer en su totalidad y llegarán a la conclusión de que la matriz es la causa de la mayor parte de las enfermedades femeninas. Es más, terminarán por atribuir al útero comportamientos autónomos. ${ }^{28}$ En el discurso dieciochesco estas imágenes e ideas con respecto a la mujer y a la maternidad se van a combinar para dar paso a una verdadera pedagogía de la maternidad que busca, en principio, la preservación del feto y su posterior nacimiento.

\section{La mortalidad infantil y la prevención del aborto}

En el siglo XVIII, el discurso higienista dirigido a las madres se relacionaba estrechamente con la preocupación por la elevada tasa de mortalidad infantil, cuya curva negativa se buscaba revertir. Dicha mortalidad fue frecuente en el parto y a lo largo de los primeros años de vida del infante durante toda la época moderna. Asimismo, fue habitual la mortandad de las madres al momento de dar a luz. En Europa ésta alcanzó cifras impresionantes debido, entre otras cosas, a las pésimas condiciones en que se producían los alumbramientos. ${ }^{29}$ La gestación, llevar a buen término el nacimiento del bebé, fue también una cuestión preocupante pues en el siglo

28 La explicación de esta evolución se ha apoyado sobretodo en el interesante estudio de Berriot-Salvadore, Evelyne: "El discurso de la medicina y de la ciencia", en Duby, Georges y Perrot, Michell. (Dir.): Historia de las Mujeres, Taurus, Madrid, 1993, págs. 109-151. pág. 611.

29 Anderson, Bonie: Historia de mujeres: una historia propia, Vol. 2, Crítica, Barcelona, 1992, 
XVIII la fuerza del Estado y la prosperidad pública se creía que estaban realcionadas con el aumento de la población. En un artículo sobre las reglas que debían observar las mujeres gestantes se prescribe que "todo el objeto de la Madre debe dirigirse a conservar su feto, precaver el aborto y facilitar un parto natural. Los preceptos de la Higiene favorecen estas intenciones..." ${ }^{30}$ En efecto, el interés por la población, propio de este siglo, se hace patente en el discurso higienista que se dirige a las madres, quienes tendrán una responsabilidad de primer orden en su aumento y conservación.

El discurso propugnado por los médicos buscaba aumentar el número de brazos que sostenían al Estado y darles una adecuada educación física y moral para hacerlos fuertes y virtuosos. Por lo tanto, la prosperidad pública dependía del seguimiento riguroso de los preceptos higienistas estipulados por los médicos. Mas no olvidemos a los fisiócratas y su manía no sólo por aumentar la producción agrícola, sino también la población humana. Ésta se vinculó estrechamente con la política demográfica de los borbones destinada a organizar una adecuada base tributaria, de la cual se servirán más tarde los gobiernos poscoloniales. El objetivo, entonces, era educar a las mujeres en la higiene física y moral, pues para la Ilustración la felicidad, fin principal de la naturaleza del hombre, dependía de la educación, que era el medio a través del cual se lograba domesticar las pasiones para transformarlas en virtudes sociales para el interés tanto personal como público. ${ }^{31}$ El optimismo de los ilustrados en la educación como instrumento para perfeccionar y reformar la naturaleza humana se extendía a las madres de familia, que deberían encargarse de la educación de sus hijos, futuros vasallos, y más adelante, ciudadanos.

En este sentido, uno de los principales objetivos del discurso médico fue evitar el aborto, por ello en varios textos se intenta ofrecer una explicación exhaustiva sobre sus causas. Para los médicos de la época existían, principalmente, tres clases principales de aborto: uno provocado por una sustancia o medicamento, otro originado en la violencia física o una intervención mecánica y el tercero, motivado por una conmoción psicológica. ${ }^{32}$ Evidentemente, la primera fue la forma más criticada de aborto, práctica al parecer bastante difundida que era comparada en el discurso con las costumbres de los pueblos más bárbaros y considerada tanto un crimen como

30 Suadel: "Disertación Primera..."

31 Iglesias, María Carmen: "Educación y pensamiento ilustrado", en Actas del Congreso Carlos III y la Ilustración, t. III, Ministerio de Cultura, Madrid, 1989, págs. 1-30.

32 Suadel: "Disertación Primera..." 
un pecado. Apelando tanto al argumento de la civilización como de la religión se descalificaba el aborto voluntario. Sin embargo, si bien la mayor parte de los especialistas en medicina de la mujer condenaban la interrupción voluntaria del embarazo por razones morales, sobre todo lo hacían por motivaciones médicas, pues la mayoría de las veces la intervención provocaba una hemorragia fatal para la madre. En este tipo de aborto inducido, según los médicos, las parteras y curanderas tenían gran responsabilidad, pues facilitaban preparados a base de hierbas que terminaban provocando a la gestante lesiones y hasta la muerte. ${ }^{33}$

Luego del análisis de los factores que llevaban a la pérdida del niño, se le daba a la madre una serie de recomendaciones prácticas - acordes con su complexión anatómica - que contemplaban aspectos como el seguir una dieta especial y llevar una forma de vida saludable. Se debían evitar, además, los malos tratos, peleas y preocupaciones en las parturientas puesto que podían originar una conmoción psicológica. Asimismo, las mujeres que se dedicaban a actividades que demandaban un gran esfuerzo físico, debían evitarlas durante la gestación, pues podían originar la pérdida del niño; pero tampoco era aconsejable una vida sedentaria. ${ }^{34}$ El tipo de vestimenta y hasta los olores eran mencionados como otras causas del aborto. Sobre lo primero, si bien hasta el siglo XX no existió una vestimenta específica para la gestante y ciertas modificaciones al vestuario femenino se intercalaron en el tiempo para adaptarlas a su estado, hacia el final del XVIII la vestimenta sufrió una enorme evolución, pues durante la gestación desaparecieron las constricciones, estructuras o bustos, primando la línea suelta y libre, con la cintura trasladada debajo del seno. ${ }^{35}$ En el Perú los médicos se preocuparon también por normar este aspecto condenando duramente el uso de faldas que ceñían el vientre impidiendo la dilatación del útero y de trajes voluminosos nocivos para la normal evolución del embarazo. ${ }^{36}$

Estas disquisiciones involucraban al feto, se intentaba explicar su crecimiento y desarrollo, su relación con la madre exponiendo los avances del conocimiento en este campo. En un escrito se leía: "Ultimamente sabemos

33 Suadel, Erasistrato: "Higiene. Carta Segunda de Erasistrato Suadel relativa á las preocupaciones que deben observarse en los Partos, en continuación en el Merc. Núm. 45", 25 de diciembre de 1791, Mercurio Peruano, t. III... págs. 292-299.

34 "Higiene. Perjudica muchas veces al estado de preñez y a la felicidad del parto la vida muy sedentaria de las mujeres" en Cabello (Ed.): Diario de Lima, 20 y 21 de noviembre de 1790.

35 Davanzo Poli, Doretta: "L'abbigliamento in gravidanza, parto, puerperio", en Capelletto, Tiziano (Coord.) Dalla Serenissima alla Prima Guerra Mondiale, Forma, Milano, 1985.

36 Suadel: "Disertación Primera..." 
que a correspondencia que el feto va creciendo, las piezas que componen un hueso se osifican, y constituyen una sola pieza o hueso, y lo que era membranoso se hace cartilaginoso, y esto huesoso...". ${ }^{37}$ De esta manera, el discurso médico ponía a disposición de las gestantes algunos conocimientos básicos de anatomía y fisiología al servicio de la maternidad a través de un medio de difusión que iba cobrando gran importancia, los periódicos. La madre ilustrada debía conocerlos para cumplir a cabalidad con la misión más importante que tenía: traer al mundo al nuevo ser. El editor del Semanario señalaba en el Prospecto: “¿No será pues utilísima ocupación hacer ver á las Señoras mugeres sus comunes defectos en este ramo tan importante á la Sociedad, desde el primer instante en que una agradable suerte las condecoró con el dulce título de Madres?"38 La crítica de costumbres $^{39}$ al lado del discurso higienista, contribuyeron a la reforma del ámbito doméstico y a redefinir el rol de la madre en su interior. Según ambos, la mujer debía favorecer el progreso de la sociedad reformando las costumbres nocivas para la maternidad.

\section{La polémica en torno de la influencia de la madre sobre el feto}

Dentro de esta preocupación por el embarazo, un tema que fue motivo de reflexión entre los médicos se refería al tipo de relación que existía entre la madre y el feto, y más específicamente, a la influencia que podía tener la madre en el desarrollo del feto. Mientras algunos autores sostenían que la imaginación de la madre influía de manera negativa en el niño que llevaba en su vientre, otros lo negaban rotundamente, y hasta se podían entrever posiciones intermedias. Un ejemplo es la nota del Mercurio que trataba sobre la desfiguración de una niña, donde su autor, si bien mencionaba las "sigilaciones tan frecuentes en el Embrión debidas a la fuerza de la fantasía de la Madre", explicaba cómo se evidenciaban los efectos de la "Raquitis" en su cuerpo. ${ }^{40}$ La discusión sobre este tema no carecía de rele-

37 Ganarrilla, Joseph Torpas de [Larrinaga, Joseph Pastor de]: "Carta escrita a la Sociedad presentándole una disertación quirúrgica”, 3 de junio de 1792, Mercurio Peruano, t. V... págs. 73-89.

38 Olavarrieta, Juan Antonio: "Prospecto", Semanario Crítico, Imprenta Real de Niños Expósitos, Lima, 1791.

39 Para una definición del artículo de costumbres véase Cornejo Polar, Jorge: "Costumbrismo y periodismo en el Perú del siglo XIX”, Lienzo, 17, Lima, 1996, págs. 367-408.

40 Aristio [Unanue, Hipólito]: "Metamorfoses humanas. Noticia de la extraña desfiguración de una niña”, 14 de julio de 1791, Mercurio Peruano, t. II...págs. 196-198. 
vancia, pues se buscaba no solamente llevar a buen término el embarazo, sino también que el fruto del vientre fuera saludable, además de desterrar creencias populares en torno de la gestación. La patología y las malformaciones congénitas fueron objeto de preocupación, y en una época signada por la prevención, se indagaba por sus causas para darles remedio.

A este respecto, un extenso artículo publicado por los mercuristas discutía el problema exponiendo una serie de casos médicos que abonaban la teoría de la influencia de la imaginación materna sobre el feto para luego refutarlos. El autor iniciaba su discurso señalando que: "El objeto de mi argumento no es otro, que el de la prolija y curiosa cuestion tratada por tan buenas plumas en diferentes tiempos, acerca del influjo de la imaginación materna respecto del feto". ${ }^{41}$ De este modo, narraba, por ejemplo, el caso de un niño que había nacido con todos los miembros fracturados a causa de que su madre había presenciado, estando embarazada, destrozar vivo a un delincuente. Seguidamente el autor exponía argumentos científicos, citando a médicos españoles e ingleses, que negaban tal idea. Planteaba que las sensaciones o sentimientos de la madre no podían imprimirse en el feto como si se tratasen de objetos y que existía una independencia entre el embrión y la madre. Sobretodo intentaba explicar las manchas en la piel de los neonatos atribuidas al influjo de la imaginación de la madre y recurrió a los brebajes de yerbas usados para abortar, las enfermedades de los padres o el mayor o menor flujo de sangre. Terminaba citando al "moderno Plinio", quien afirmaba que: "el Feto no está asido inmediatamente a la matriz, ni ligado a ella sino por unos pesonsillos exteriores de sus túnicas, ni tiene su sangre comunicación alguna con la sangre de la madre, y en una palabra, ... en cierto modo es tan independiente de la madre que le lleva en su seno, como el huevo es independiente de la gallina que lo empolla". ${ }_{42}$

Los efectos de la fisiología uterina sobre el feto remitían a la relación establecida entre este y la madre, cuya interpretación varió al vaivén del desarrollo de las concepciones médicas sobre la reproducción y el rol que cabía a cada uno de los sexos en tal proceso. Esto se relacionaba también con la determinación del sexo del bebé, la mayor o menor semejanza a los padres y hasta el color de la piel, temas abordados en los escritos analizados. Una noticia del Diario de Lima, por ejemplo, se refería a que el estado de la luna cuando se daba el parto servía como anuncio sobre la calidad

41 Rebollar, Francisco de: "Carta remitida a la Sociedad sobre la conjetura de la niña de Cotabambas", 26 de diciembre de 1793, Mercurio Peruano, t. IX, 1966, págs. 267-274.

42 Rebollar: "Carta remitida...". 
o sexo del feto. ${ }^{43}$ Entonces, se cuestionaba la idea difundida sobre el influjo de la imaginación materna en el neonato apelando a argumentos ilustrados y racionalistas, y se ofrecían explicaciones médicas de tales anomalías, como por ejemplo los estragos que podía causar en el feto el mal venéreo. A este respecto, encontramos otras referencias a esta idea de que a raíz de las enfermedades venéreas nacían niños con malformaciones. En una noticia se mencionaba que: "Del mal venereo... sabemos que se comunica, y tenemos demasiados ejemplos de niños, que desde su nacimiento han sido víctimas de la vida licenciosa de sus Padres". ${ }^{44}$ Tanto es así que se publicó en el Mercurio una receta para enfermedades venéreas. ${ }^{45}$ En esta "pastoral del miedo", como la denomina Jean Delameau, el médico terminaba siendo más eficaz que el sacerdote: las consecuencias de los actos inmorales se evidenciaban en la salud de la persona y la enfermedad era una manera de expiar las culpas.

\section{Los antojos de las embarazadas: ciencia o superstición}

Dentro de esta misma discusión, uno de los aspectos que preocupó a los médicos fue el de los antojos de la madre y su influencia sobre el niño. Varias son las referencias a este tema que advierten sobre los males que puede acarrear al feto la satisfacción de los depravados apetitos de la madre, que al iniciar el embarazo aún no había desarrollado un instinto maternal. Esto interesaba porque en muchas ocasiones se intentaba dar una explicación de las deficiencias en la salud o malformaciones del niño a partir de los problemas durante el embarazo. Para los médicos modernos era claro que el hombre no era el único que influía en el bebé, también la mujer influenciaba el desarrollo psicológico del niño. Esto último preocupaba mucho porque la gestante mostraba, a ojos de los médicos, una fisiología en desorden y una alteración psíquica evidente por sus síntomas de ansiedad, hinchazón de los senos, manchas en el rostro, entre otros signos propios de su estado.

A este respecto, es ilustrativo el artículo escrito por Cosme Bueno titulado "Disertación sobre los antojos de las mujeres preñadas", que apa-

43 Cabello (Ed.): Diario de Lima, 31 de enero de 1791.

44 Rebollar: "Carta remitida...".

45 Anónimo: "Publicación de una receta por Real Orden con una nota previa por el señor oidor Presidente de la sociedad...", 6 de febrero de 1794, Mercurio Peruano, t. X, págs. 84-93. 
reció en El Conocimiento de los tiempos, ${ }^{46}$ pequeña publicación que acompañaba a los periódicos o se distribuía junto con la Guía de Forasteros. Es significativo que el texto haya sido publicado en dos oportunidades, en 1794 y 1796. Este médico, al igual que muchos de sus contemporáneos, explica la existencia de antojos debido a la desmesurada imaginación de las madres. El antojo era definido como el apetito vehemente de alguna cosa que podía ser extraña o usual, que si no era satisfecha dentro de cierto tiempo podía llevar a las embarazadas a realizar actos desde extravagantes hasta poco decentes. Si bien esto era cierto, Cosme Bueno afirmaba que los frecuentes abortos y las deformaciones con que nacían los bebés no se debían al incumplimiento de los antojos de las embarazadas, sino a su descarriada imaginación, que terminaba por trasmitir al feto enfermedades y estados de ánimo. De esta manera, los procesos físicos y fisiológicos de la mujer gestante se vinculaban con su psiquis. Esta idea sobre las malas consecuencias que acarreaba la insatisfacción de los antojos, se relacionaba con la antigua creencia de que el útero dominaba a la mujer y hacía de ella un ser extremadamente sensible, con una fecunda imaginación, un ser exaltado y pasional. Si estaba gestando peor aún, porque estas características se acentuarían mucho más. Por ello, la mujer embarazada aparecía en las disquisiciones de médicos e intelectuales como un ser difícil de entender y conceptualizar por su mayor propensión a la irracionalidad en esas circunstancias. Al final el médico era como una especie de exorcista que luchaba contra las fuerzas irracionales femeninas siempre amenazadoras del embarazo y el feto. El discurso ilustrado buscaba desterrar viejas creencias y supersticiones, difundidas sobre todo entre las mujeres y el pueblo, para abrir paso a la ciencia.

\section{Hacia la moderna obstetricia: diatriba de la partera y apología del médico}

Uno de los aspectos más importantes del siglo XVIII se relaciona con el prestigio cada vez mayor que fue logrando el discurso científico, como legitimación del rol público de los médicos, quienes debían señalar al Estado y a los individuos los derroteros por donde debían discurrir sus

46 Bueno, Cosme: "Disertación sobre los antojos de las mujeres preñadas", El Conocimiento de los Tiempos, Imprenta Real, Lima, 1789-1796. 
hábitos y comportamientos, tanto a nivel físico como moral, con el fin de obtener la ansiada salud individual y pública. Esta debía estar por completo en manos de los médicos, los que directamente o a través de la conducción y tutela de los empíricos, se debían encargar del cuidado del cuerpo. En el campo de la maternidad, desde muy antiguo fue destacada la presencia de parteras, comadronas o curanderas, entre otras representantes del saber empírico, que se encargaban de asistir a la madre durante la gestación y, sobretodo, al momento del alumbramiento. Este estado de cosas se buscará revertir en el Siglo de las Luces y los borbones realizarán una ardua campaña destinada a lograr una formalización del saber y a desterrar la informalidad de la práctica por los graves riesgos que acarreaba. Hay que considerar que en el siglo XVIII dos cosas se hicieron evidentes para los soberanos y los gobiernos ilustrados: que la formación de los médicos debía ser funcional y útil, y que debía existir una regulación de la práctica médica en general. A las parteras y comadronas, mayormente eran mujeres las dedicadas a este menester, se les achacaba el ser las principales responsables de la mortalidad de los infantes y hasta de las parturientas, por su falta de conocimiento e ignorancia. Un testimonio escrito de la época recitaba así: "se echa la culpa de la despoblación de España a una serie de causas, que todas juntas no equivalen a una sola comadrona, a una madre caprichosa". ${ }^{47}$

Frente a esta situación, se inició a través del Protomedicato, en España y América, una campaña auspiciada por los borbones para evaluar la competencia de estas mujeres. Se exigió que fuesen personas alfabetas con conocimientos teóricos y prácticos sobre el embarazo y el parto; pero, además, como requisitos estaban la fortaleza, la buena salud y la discreción para no comprometer la reputación de las madamas. Asimismo, debían demostrar tener nociones mínimas de anatomía de la región pélvica y del aparato genital femenino. ${ }^{48}$ En el Perú ocurriría lo mismo; en este sentido, entendemos la crítica de Unanue a las parteras al señalar que no tenían la calificación ni las virtudes necesarias para ayudar a las gestantes en la labor de parto, y que ello se debía a que, en general, su procedencia social era de origen humilde. La más grave de las deficiencias, según el reputado médi-

47 Olavarrieta: Semanario Crítico, N. $^{\circ} 12 \ldots$

48 Tate Lanning, John: De Royal Protomedicato. The regulation of the Medical Professions in the Spanish Empire, Duke University Press, Durkem, 1985, citado en O’Phelan: “'"Que la muerte no me coxa desprevenido". Testamentos de mineros en el tránsito del siglo XVIII al XIX”, en Félix Denegri Luna Homenaje, PUC, Lima, 2000, págs. 571-597. 
co, era la falta de conocimiento de la anatomía. ${ }^{49}$ Por su parte, Olavarrieta señalaba que "Con justísima razón esta prohibido el exercicio de estas funciones a mugeres ignorantes, que no tengan suficiencia para sufrir un riguroso examen sobre el manejo de los niños"..$^{50}$ En adelante, las parteras y comadronas debían ser formadas, examinadas y supervisadas rigurosamente por los médicos, que debían tutelar el cuerpo femenino. Este discurso se entiende dentro del marco de profesionalización del saber propugnado por la Ilustración y la importancia que va cobrando la higiene pública. ${ }^{51}$

La diatriba en contra de la partera tenía su contrapunto en la apología del médico. Frente a las prácticas supersticiosas y poco científicas de las parteras, el discurso ilustrado sacaba a relucir la figura del médico, poseedor de la ciencia y la experiencia. Justamente, el binomio inseparable que unía teoría y práctica, era el fundamento de un saber científico que finalmente debía ser útil.

Olavarrieta las atacó duramente desde las páginas del Semanario, refiriéndose a ellas como "chusma de comadronas, ó parteras, cuya ignorancia, y adulación ha inventado tantos lazos de perdicion contra la humanidad". 52 En este contexto, los médicos lamentaban la ausencia de mujeres formadas en este campo en una ciudad tan populosa como Lima y hablaban de la imperiosa necesidad de desarrollar la moderna obstetricia, con el fin de "evitar los frecuentes daños que ocasiona la ignorancia de nuestras parteras". El argumento de la ignorancia es recurrente en el discurso higienista para descalificarlas y sobre este punto, el médico que escribe bajo el seudónimo de Erasistrato Suadel afirmaba:

“...que esta parte tan útil de la Cirugía, no ha logrado aun entre nosotros aquella perfección que se merece. Las parteras de Lima se apropian este título, sin mas principios ni reglas que una asistencia ciega, y sin mas conocimientos que los que ofrece la experiencia propia....".53

Desde su perspectiva, las parteras y comadronas tan solo se dedicaban a recibir el feto y cortar el cordón umbilical, en lo cual podían hasta ser

49 Unanue, Hipólito: "Decadencia y restauración del Perú. Oración inaugural que para la estrena y abertura del Anfiteatro Anatómico, dixo en la real Universidad de San Marcos el día 21 de Noviembre de 1792...”, 1793, Mercurio Peruano, t. VII, BNP, Lima, 1965, págs. 82-127.

50 Olavarrieta: Semanario Crítico, $\mathrm{N}^{\circ}{ }^{\circ} 12$.

51 Suadel: "Hygiene. Carta dirigida a la sociedad por el despacho del Mercurio", 1791, Mercurio Peruano, t. II, págs. 87-88.

52 Olavarrieta: Semanario Crítico, N. ${ }^{\circ} 12$.

53 Suadel: "Higiene. Carta segunda..." 
diestras; sin embargo, esto no era suficiente. La carencia de una adecuada formación unida al desconocimiento de los elementos teóricos más elementales hacía, en opinión de los médicos, que las parteras se circunscribieran a la sola experiencia para desarrollar su tarea; lo cual devenía, muchas veces, en la necesidad de la presencia de un cirujano que asistiera el parto. Es más, debido a esta situación, señalaba que no había ninguna mujer capaz de instruir en esta materia a las que querían seguir ese oficio y que era necesario que las autoridades nombraran a un perito para la adecuada formación de estas mujeres, que detentara la facultad de privar del oficio a las que no recibieran sus enseñanzas.

Además, Olavarrieta advertía que era imprescindible contrarrestar la influencia que ejercen las parteras sobre las madres, quienes les hacían más caso a ellas que a los propios médicos. La partera, con la anuencia de la parturienta, procedía a su labor por lo que el editor del Semanario afirmaba despectivamente que "tanta chusma de viejas parteras, curanderas y emplasteras, cuya ignorancia con una vil inclinación a la lisonja pervierte, y arrastra en pos de si una gran parte del Estado, y la mayor parte del vello Sexo" ${ }^{54}$ Del mismo modo se expresaban los mercuristas cuando las denominaban charlatanas y curanderas que tenían "la habilidad de engañar al vulgo inexperto"..$^{55}$ Como vemos, las mujeres y la plebe, la parte de la sociedad que más se debía ilustrar, eran propensas a creer en este tipo de saber empírico y supersticioso, por lo cual a ellos principalmente se se iba a dirigir el mensaje de los médicos higienistas e intelectuales que buscaban la reforma de las costumbres. Sin embargo, la agresividad de los ataques podía revelar en el fondo el gran poder que detentaban estas mujeres por la misma naturaleza de su oficio. ${ }^{56}$ Entonces, en el discurso higienista, las reflexiones teóricas se combinaron con el pragmatismo impulsado por la Ilustración para educar, especialmente, a la mujer y al pueblo. Los médicos, depositarios del saber, tenían en sus manos la tutela del cuerpo no solo individual, sino también del cuerpo social en su conjunto. Estas críticas a la labor de parteras y comadronas evidenciaban la vocación de divulgar los preceptos higienistas, que animaban los presupuestos científicos y médicos

54 Olavarrieta: Semanario Crítico, N. ${ }^{\circ} 12$.

55 Suadel: "Disertación Primera...."

56 El temor a las parteras tenía orígenes antiguos y se vinculó con la labor de las hechiceras, brujas y curanderas, quienes constituían una amenaza por el gran poder que detentaban y en consecuencia fueron perseguidas. Véase Flores, Javier: "Hechicería e idolatría en Lima colonial, siglo XVII", en Urbano, Henrique (Comp.) Poder y violencia en los Andes, CBC, Cuzco, 1991, págs. 53-74. 
de la época. Se empleó la prensa como medio y en ella se plasmaron las recomendaciones conducentes a llevar un adecuado embarazo que concluyese en un exitoso parto.

\section{Dando a luz de manera natural}

Las mujeres embarazadas se encontraban en un estado de sumo cuidado durante la gestación y en el mismo momento del alumbramiento debido a múltiples factores: por un lado, estaba la frecuencia y el elevado número de embarazos por los que pasaban a lo largo de su vida; por otra parte, la carencia de medicamentos que pudieran calmar los dolores o servir de antisépticos; a esto se sumaban las condiciones poco higiénicas en las que se realizaba el parto, la falta de una asistencia adecuada o la poca práctica de procedimientos como la cesárea. ${ }^{57}$ Todo ello contribuía a hacer más delicada e incierta la situación de la mujer gestante. El parto, momento culmen de este proceso, ponía en riesgo la vida de la madre y el neonato, como lo demuestra la elevada tasa de mortalidad de mujeres y niños en esas circunstancias. Una mención ilustrativa al respecto señala que una mujer "había tenido la desgracia en tres ocasiones diferentes de parir muertos los hijos a los nueve meses cumplidos". ${ }^{58}$

El cuidado que debía tenerse durante el parto, entonces, fue motivo de reflexión y orientación pedagógica por parte de los médicos. En este punto, el discurso ilustrado, que buscaba la comodidad y el menor dolor de la madre, se rebelaba contra el religioso que mandaba a la mujer parir con gran sufrimiento debido a la desobediencia de Eva. A las justificaciones teológicas de antaño se opusieron las observaciones científicas del momento que explicaban el dolor de la parturienta y las dificultades del parto. Argumentos esgrimidos para explicar los dolores y problemas a la hora del parto, se referían al tamaño de la cabeza del feto y, sobre todo, a la falta de costumbre de las mujeres de las sociedades civilizadas para realizar trabajos duros y a sus hábitos sedentarios. Los padres de la obstetricia -Ambroise Paré, François Mauriceau y Rösslin - se apiadaron del sufrimiento de las mujeres que debían dar la más difícil de las pruebas que era

57 Uno de los problemas que se podía presentar era la asfixia como muestra una noticia titulada "Observaciones acerca del medio más eficaz para restituir a la vida los niños que parecen haber nacido muertos" en Cabello (Ed.) Diario, 12 y 13 de noviembre de 1790.

58 Ganarrilla: "Disertación de cirugía sobre un feto..." 
el alumbramiento. Entonces, los médicos ofrecieron una serie de consejos para ayudar a la madre a pasar esa penosa y difícil prueba en la que hasta podía perder la vida. Sin embargo, la piedad de los médicos era ambivalente, pues por una parte salvaba a las mujeres del desprecio y, por otro lado, afianzaba todas las representaciones de la debilidad femenina. En los artículos periodísticos se encuentran detalladas descripciones de la forma en que se debe dar a luz, siguiendo los principios de higiene y salud de la época. Entonces, fue constante en el discurso ilustrado la preocupación por la asistencia en los partos y la divulgación de los argumentos que explicaban su naturaleza. Una descripción detallaba cómo:

"el feto se precipita; los nervios del segmento inferior del útero se aflojan; los humores contenidos en sus vasos se cuelan: el licor del amnios sale con el feto; el fondo se vacía; disminuyendo la resistencia se contrae con más fuerza; y hallándose franca la salida, cae el feto a plomo por su propio peso". ${ }^{59}$

De esta manera, los médicos pretendían instruir a las mujeres preñadas para evitar los problemas durante el parto y preservar la vida tanto de la madre como del niño. Para explicar el parto natural se recurría a la tradición de Galeno e Hipócrates y a las autoridades de la ciencia médica moderna. Si bien hacían referencia al saber especializado y a la tradición, las recomendaciones presentaban una gran dosis de pragmatismo. Los cirujanos señalaban que para facilitar las contracciones del útero y los músculos del bajo vientre se debían superar tres circunstancias: la distensión de los intestinos y de la vejiga, la plenitud sanguínea de los vasos uterinos y la mala posición. Para aliviar la distensión de los intestinos era recomendable la frugalidad en los alimentos y lavativas que evitasen la salida de las heces durante el parto. Cierto tipo de mujeres definidas según su anatomía, debían sangrarse en ese momento siguiendo la idea de Hipócrates de la necesidad de la sangría durante el trabajo de parto. Galeno y sus seguidores confirmaron la teoría hipocrática y postularon que se debía sangrar el pie, pero los médicos ilustrados, que conocían la circulación de la sangre, refutaron la idea galénica y afirmaron que debía aplicarse la sangría al brazo. Sin embargo, los ilustrados peruanos señalaban que podía usarse uno u otro método según las circunstancias.

Con respecto a la posición de la parturienta se señalaba que la mejor y más adecuada para la complexión femenina era de pie cuando se inicia-

59 Suadel: "Higiene. Carta segunda..." 
ban los dolores. Así, se pasaba a explicar los movimientos que debía hacer la madre y cómo la debía asistir la comadrona. La moderación en el uso de las unturas oleosas podía ser conveniente. Siguiendo estos consejos, el parto debía cumplirse del modo más natural. Pero, si las secundinas o placenta no seguían al feto, debía darse un segundo parto después de comprobar si existía otro feto o dar emolientes a la parturienta y ligeras sacudidas al cordón evitando las hemorragias. Los médicos recomendaban no usar lavativas, supositorios, inyecciones y purgantes, que eran perniciosos y podían causar graves consecuencias. Pero sí aconsejaban desprender la placenta del útero con la mano de tal manera que no se produjera una hemorragia, que era lo más peligroso. ${ }^{60}$ Asimismo, se criticaban costumbres nocivas como el grave error de no lavar a los niños después de nacer así como el aplicar braseros y aromas a los cuartos de las gestantes que acababan de dar a luz. ${ }^{61}$ De esta manera, quedaban evidenciados en el discurso destinado a las madres los criterios de racionalidad, utilidad y orden caros a la Ilustración. Así, el embarazo y el parto fueron objeto de atención en tratados y escritos periodísticos que respondían a la voluntad dieciochesca de difundir el saber médico. El parto era visto como un momento muy peligroso tanto para la mujer como para el niño, en el cual debía intervenir el médico para aliviar los dolores y facilitar el nacimiento del bebé. No sólo se daban recomendaciones para tener un parto normal, pues también hay referencias a partos problemáticos o extraños que daban lugar al nacimiento de seres anómalos. El afán pedagógico estaba siempre presente en la exposición de estos casos edificantes a la vez que se apelaba al miedo, a la razón o a la moral del público lector para educar en higiene y salud.

\section{Partos problemáticos, monstruosidades y malformaciones}

La insistencia del discurso médico en las precauciones que debían tener las mujeres embarazadas se vinculaba no sólo con la frecuencia de las pérdidas y la alta tasa de mortalidad en el parto y en los primeros años del infante; sino también, y no debe olvidarse, con el hecho de que para estos hombres, el embarazo, aun cuando evolucionara sin complicaciones, cons-

60 Suadel: "Higiene. Carta segunda...".

61 Olavarrieta: Semanario Crítico, N. ${ }^{\circ} 11 \ldots$ 
tituía un estado patógeno que involucraba perturbaciones físicas y alteraba el equilibrio psicológico de la mujer. De por si la mujer era vista más como el ser de la pasión, antes que de la razón; con una imaginación sin límites y con sentimientos desbordantes, pues estaba dominada por el útero. Entonces, cuando estaba gestando, todo ello se acentuaba y la mujer en estado terminaba siendo un ser de difícil conceptualización. Por eso, se desarrolló todo un imaginario del embarazo plagado de fantásticas historias sobre los irreprimibles deseos de las embarazadas, sus apetitos depravados y los nacimientos monstruosos a que daban lugar.

Esta temática revelaba la recurrente preocupación por la población no sólo de carácter cuantitativo, sino también un interés de índole cualitativo. En efecto, era importante que la mayor cantidad de niños nacieran pero también que fueran sanos y se desarrollaran normalmente; y como debido a los avances científicos se puso en evidencia la relación entre la madre y el feto, se consideraba que el período de gestación era importante para el posterior desarrollo del niño. El trasfondo de estas inquietudes se relacionaba con la creciente seguridad que fue cobrando en el siglo XVIII la idea del perfeccionamiento indefinido de la especie humana. ${ }^{62}$ Buffon será uno de los primeros en pensar en las transformaciones posibles de una especie de generación en generación y a partir de ello se recurrirá al uso de criterios morfológicos para evaluar tales cambios. Sin embargo, existió también el espectro de una degeneración de la especie humana, por lo que los proyectos médicos destinados a su perfeccionamiento se multiplicaron después de la mitad del siglo XVIII, alentados por la seguridad de que los cuerpos eran perfectibles. La higiene aspiraba a perfeccionar la naturaleza humana en general.

No obstante la orientación científica y racionalista de los cirujanos dedicados a la obstetricia, se desplegaron entonces una serie de creencias de raigambre muy antigua que narraban historias de partos complicados, nacimientos asombrosos, mostruosidades y malformaciones, historias transitadas por gigantes, deformes o longevos. Un caso ilustrativo es el artículo de Joseph Pastor Larrinaga que trataba sobre la cirugía de un feto de nueve meses que una mujer parió a través del conducto urinario. ${ }^{63}$ Este tipo de noticias estaba sujeto a múltiples lecturas y disímiles interpretaciones de

62 Vigarello, Georges: Histoire des pratiques de santé.Le sain et le malsain depuis le Moyen Age, Editios du Seuil, Paris, 1999, pág. 157.

63 Ganarrilla: "Carta escrita a la Sociedad...", 31 de mayo de 1792: págs. 65-72; 3 de junio de 1792: págs. 73-89; 7 de junio de 1792: págs. 81-84, Mercurio Peruano, t. V... 
acuerdo con la persona que lo leyera. ${ }^{64}$ Podían generar curiosidad, temor o interés, siendo, por un lado, parte de la temática abordada por la Ilustración que rediseñó el paradigma de la normalidad sobre el fundamento de la naturaleza; y, de otra parte, un recurso empleado por los intelectuales para educar apelando al temor, la exageración o la curiosidad. Al lado de este imaginario se encontraban las descripciones científicas producto de la observación y la experimentación en las que los médicos describían los síntomas de la madre, los tratamientos a los que eran sometidas y los procedimientos adecuados en partos problemáticos como el caso de la cesárea. Recordemos que el discurso ilustrado peruano era alimentado por la reivindicación de los criollos frente a las críticas de los autores europeos ${ }^{65}$ por tanto, se buscaba mostrar cómo los conocimientos y grandes avances científicos del momento eran aplicados con éxito en el país.

\section{La cesárea como una operación médica necesaria}

Uno de los temas que preocupó a los médicos higienistas, interesados por incorporar los nuevos avances científicos europeos al país y por el aumento de la población, fue la cesárea. Esta se había practicado en Europa durante mucho tiempo, pero en la madre muerta; sin embargo, en la época moderna se discutió si debía realizarse cuando la madre estaba viva, pues se ponía en riesgo su vida, lo cual constituía un grave problema de conciencia para el médico que se debatía entre salvar a la madre o al neonato. El año de 1581 es el punto de partida de la historia del corte cesáreo en la mujer viviente, pues ese año François Rousset sostuvo que la extracción del neonato a través de un corte lateral del vientre y del útero era posible en la mujer viva sin perjuicio de su vida y la de futuros embarazos. La teoría levantó polémica por el riesgo de la intervención ante lo cual los médicos argumentaron que no se debía cometer el homicidio consciente de la madre a favor del niño que debía nacer. Durante todo el siglo XVII y buena parte del XVIII el corte cesáreo sobre la madre viva

64 Chartier señala que se deben considerar las diversas estrategias de lectura, las caracteríticas de la comunidad de lectores y la manera en que el texto llega a sus manos, cuestionando la tradicional idea de que el contenido de los textos era leído y entendido de la misma forma por todo el público lector. Chartier, Roger: El Mundo como Representación, Gedisa, Barcelona, 1992.

65 Gerbi, Antonello: La disputa del Nuevo Mundo. Historia de una polémica, 1750-1900, FCE, México, 1960. 
será tema de debate y controversia —exclusivamente teórica- entre los médicos, hasta que en 1745 Francisco Manuel Cangiamila, publicó la obra más completa sobre la cesárea, rica en casuística y reflexiones. No obstante dicha polémica, la cesárea se practicó y su difusión estuvo relacionada con el hecho de que a partir del siglo XVII se demostró que era anatómicamente posible y a ello se sumó la actitud de los religiosos que se mostraron favorables a dicho procedimiento sosteniendo que era importante para la salvación del alma del niño a través del sacramento del bautismo. Frente a esta postura, los médicos encabezados por el obstetra François Mauriceau se opusieron defendiendo la autonomía de su labor, en la que no debían prevalecer criterios religiosos que justificaran el sacrificio de la madre en pos del neonato. ${ }^{66}$

En el Perú, como se desprende del discurso, ni siquiera la cesárea en la madre difunta era realizada debido sobretodo a la negativa de la población. Ante esta situación, en el siglo XVIII autoridades y médicos expresaron que la resistencia a realizar cesáreas era uno de los factores principales de que muchos embarazos no llegaran a buen término, produciéndose la muerte de la madre y el bebé. Entonces, los médicos higienistas y el Estado, imbuidos de las ideas racionalistas y científicas, buscaron educar a la población para la aceptación de tal procedimiento. Los ecos del debate europeo se dejaron oír con fuerza cuando en el año 1781, el clérigo regular de la Buena Muerte, el Padre Francisco González Laguna, publicó la obra titulada El zelo sacerdotal para con los niños no nacidos, que justamente se refería al polémico tema. El destacado miembro de la Sociedad de Amantes del País defendía fervorosamente la cesárea por el avance científico que implicaba, pero empleando un argumento de carácter religioso y apelando al miedo de la condenación eterna que el neonato sufriría al no recibir el bautismo. Así, planteaba en la obra el problema que se generaba al morir una mujer embarazada dejando a la criatura privada del bautizo y proponía como solución el practicar la operación cesárea en la fallecida para poder darle el sacramento al niño. Con argumentos de orden religioso y moral, el sacerdote no sólo buscaba convencer al público lector, sino también exponer científicamente cómo se debía desarrollar la operación, convirtiéndose la obra en una suerte de manual práctico, en que se explicaban detalladamente los pasos que se debían

66 Sobre el tema se ha consultado Berriot-Salvadore: "El discurso de la medicina...", Capelletto, Tiziano: "Parto come guerra. Storie di confronti, scontri e armi sulla scena della nascita", en Capelletto (Coord.): Dalla Serenissima... 
seguir. ${ }^{67} \mathrm{Su}$ intención era, en el fondo, salvar la vida del neonato cuando en el parto se presentaban dificultades. El mismo año de edición de la obra y contando con su apoyo, el virrey Agustín de Jáuregui ordenó que la operación cesárea se practicara en el Perú. ${ }^{68}$ Según el virrey, la medida tenía como objetivo "la felicidad eterna de los niños encerrados en los vientres de sus madres, que no pueden recibir el sacramento del bautismo por el ningún uso que tiene en estas partes la Operación Cesárea". Así, frente a la obstinación de los parientes, cirujanos y obstetrices en negarse a realizar la cesárea en caso de fallecer una mujer embarazada, el virrey disponía la obligatoriedad de la intervención.

El debate no era ajeno a las preocupaciones de los médicos peruanos. Sobre el tema, en el Mercurio Peruano apareció un artículo que narraba cómo en Tucumán se había llevado a cabo la operación en una zamba embarazada al día siguiente de su deceso, a pesar de la negativa de los familiares. Como resultado de la cesárea, nació un varón que se mantuvo vivo muy poco tiempo después de bautizado. El autor anónimo señalaba amargamente que la criatura hubiera vivido si es que se hubiese hecho la intervención apenas sucedida la desgracia y concluía advirtiendo a los lectores sobre la importancia del cuidado de la salud del alma y el cuerpo. ${ }^{69} \mathrm{El}$ tema de la cesárea se enmarcaba, entonces, en un discurso médico higienista centrado no solo en la higiene física, sino también, moral. A su vez, Hipólito Unanue se pronunció sobre el tema, en el discurso de inauguración del Anfiteatro Anatómico que después fuera editado en el Mercurio, argumentando a favor de la cesárea practicada en la madre viva conjugando medicina y anatomía en un binomio insepara-

67 Primero, se debía comprobar el fallecimiento de la madre por medio de tres pruebas: la desfiguración del rostro, la rigidez corporal y el empañamiento de los ojos o pérdida de la transparencia de la córnea. Luego se podía proceder a la cesárea, para lo cual el sacerdote recomendaba descartar el uso de la incisión en cruz y más bien realizar un corte "a lo largo, por si no han calificado bien los signos de muerte y resultara no estarla, el cierre de la herida resultaría más fácil". A continuación detalla cómo se debía proceder a "cortar los tegumentos y los músculos, quedando al descubierto la membrana del abdomen llamada peritoneo. Estando al descubierto los intestinos, debían ser apartados y proceder a buscar el útero entre el recto y la vejiga". Entonces, se debía abrir la matriz suavemente y encontrado el feto, "si se conoce estar moribundo, se bautizará sin moverlo de allí, mas si se aprecia vigoroso se cortará la vid y se sacará y bautizará con más espacio. Hecho esto se ligará el cordón umbilical a dos dedos del ombligo y se cortará a medio dedo más arriba de la ligadura". González Laguna, Francisco: El zelo sacerdotal para con los niños no nacidos, Imprenta de los Niños Expósitos, Lima, 1781.

68 Bando del virrey Agustín de Jaúregui fechado el 25 de setiembre de 1781. Anatasio Fuentes, Manuel (Ed.): Memoria de los Virreyes, Lima, 1859.

69 Anónimo: "Operación cesárea", 8 de enero de 1795, Mercurio Peruano, t. XII, 1966, págs. 111-112. 
ble. ${ }^{70}$ Con postulados científicos ponía de relieve la labor del médico durante el parto y explicaba cómo la anatomía femenina permitía semejante intervención. Entonces, ciencia y naturaleza, bases del discurso ilustrado, permitían dar a luz al feto y conservar la vida de la madre, favoreciendo el aumento de la población y, por ende, la prosperidad pública. Sin embargo, nacido el bebé no se piense que terminaba la labor del médico, los especialistas en medicina de la mujer no dudaron en introducir en sus tratados instrucciones sobre cómo llevar adelante a los hijos y la familia. El médico ejerció el papel de moralista, convirtiéndose en el consejero privilegiado de las familias y el garante científico de los valores morales dominantes, pues todas las mujeres podían dar a luz, pero no todas lograban ser buenas madres.

\section{El amor maternal, la educación y la familia ilustrada}

El amor maternal, de acuerdo con Elisabeth Badinter, no debemos olvidar que es un producto cultural y el contexto estudiado formó parte de la construcción de la madre y de la familia ilustrada. ${ }^{71} \mathrm{El}$ amor materno fue visto por los ilustrados como un sentimiento que surgía en la mujer luego de nacido el hijo y se expresaba en una serie de comportamientos y manifestaciones que fueron descritos y valorados por el discurso médico. En efecto, mientras el neonato estaba en el vientre, la madre no había desarrollado el instinto maternal, que sólo surgirá luego de nacido el bebé. Por eso los médicos debían ejercer una tutela acusiosa de las embarazadas para que no atentasen contra la seguridad y salud del feto. En principio, para demostrar un verdadero amor maternal era necesario seguir los preceptos médicos de higiene y salud durante la gestación; pero sobre todo, ya nacido el vástago, amamantarlo de sus pechos y cuidarlo personalmente sin dejarlo en manos de extrañas. Esto respondía a una campaña publicitaria que ide-

70 Unanue, Hipólito: “Decadencia y restauración del Perú. Oración inaugural que para la estrena y abertura del Anfiteatro Anatómico, dixo en la Real Universidad de San Marcos el día 21 de Noviembre de 1792...", 1793, Mercurio Peruano, t. VII, 1965, págs. 82-127.

71 Para una evolución del concepto de amor maternal a partir del siglo XVIII es interesante el trabajo de Badinter, Elizabeth: L'amore in piú: storia dell'amore materno, Longanesi, Milano, 1981. La autora propone como los tres signos de la indiferencia: la reacción frente a la muerte del niño, el amor selectivo ante la mortalidad infantil y el rechazo a dar de mamar; luego, explica los tres actos del abandono: el envío al ama de leche o de cría, el encargo de la educación a un tutor o tutora y la partida para el colegio. A partir de ello, analiza como la Ilustración critica duramente estas costumbres y en su lugar construye el amor materno como producto cultural. 
alizaba el amor materno, exaltando una relación más estrecha entre madre e hijo, reflejada en la lactancia materna. En el discurso ilustrado europeo, la madre era madre sólo si amamantaba a su bebé y lo criaba, por eso se articuló un discurso en contra de la costumbre de emplear amas de leche para tal fin. Este era un tema polémico que desde el siglo XVII se discutía en los tratados médicos y filosóficos, cuyos ecos se prolongarían durante la centuria siguiente. En el contexto peruano dicha polémica se dio también, aunque con características diversas, mientras el ideal burgués de la madre se iba configurando y un nuevo modelo de familia emergía.

\section{La lactancia materna y las amas de leche}

La importancia atribuida a la lactancia en los tratados de médicos higienistas e intelectuales del siglo XVIII se debía, como sintetiza Mónica Bolufer en una frase feliz, a que constituía la "metáfora de la maternidad", ${ }^{72}$ pues en ella se manifestaba el ideal de madre que prodigaba a sus vástagos todo el cuidado y la protección debidos. La lactancia materna tuvo la fuerza de un símbolo, era expresión de la maternidad en todos sus aspectos. Entonces, en una época en la que se estaba llevando a cabo una redefinición de la imagen materna, el tema de la lactancia atrajo mucho el interés de intelectuales y hombres de ciencia, quienes dirigieron a las mujeres sus consejos amparados en el prestigio de su arte.

El discurso sobre la lactancia materna tuvo que enfrentarse en el Perú a una práctica que se prolongó durante el siglo XIX y hasta entrado el siglo XX: la de recurrir a las amas de leche. En la época que estudiamos se realizó una campaña propagandística contraria de la cual el Semanario Crítico fue el abanderado. Desde ese medio su editor español Antonio Olavarrieta resaltó enfáticamente los perjuicios que ocasionaba dicha costumbre. A través de sus páginas, el sacerdote criticaba la difundida costumbre de emplear a las amas de leche para amamantar a los recién nacidos y, al igual que sus contemporáneos europeos, defendía la necesidad de la leche materna para el normal desarrollo del niño. Sin embargo, desde los demás periódicos de la época se escuchaban voces más indulgentes, como la del Mercurio, y hasta de aceptación de dicha práctica, como testimonia el

72 Bolufer, Mónica: Mujeres e Ilustración. La construcción de la feminidad en la España del siglo XVIII, Institució Alfons El Magnanim y Diputació de Valencia, Valencia, 1998. 
Diario a través de los repetidos anuncios donde se vendían o alquilaban amas de leche. ${ }^{73}$ Estas diferencias se debían a que los periódicos respondían al carácter heterogéneo que adoptó la Ilustración en el país, por lo que cada publicación tuvo su propia orientación y sus propios temas de interés, muestra de ello es la polémica entre el Mercurio y el Semanario, que representó el enfrentamiento de dos proyectos ilustrados. Mientras el Mercurio manejaba los grandes temas de la ilustración orientándose al grupo dirigente de la sociedad colonial, el Semanario ponía la ilustración al servicio del hombre común y se dirigía a un público más amplio, constituido no sólo por el grupo dirigente, sino también por los sectores altos de los grupos populares urbanos a los que buscaba ilustrar. ${ }^{74}$ En el caso de la lactancia materna, como ha distinguido Margarita Zegarra, no hubo una sola voz, dado que los editores del Mercurio no pretendieron desafiarla dado que era una costumbre de la clase alta local. ${ }^{75}$

La lactancia era una cuestión vital y la obra de Hipólito Unanue titulada Observaciones sobre el clima de Lima y sus influencias en los seres organizados, en especial el hombre, publicada en 1812, es ilustrativa a este respecto. Sobre el particular, el médico ilustrado señalaba que "La leche es el primer alimento que nos ofrece la naturaleza en los pechos de nuestras madres...." ${ }^{76}$ Para él la leche era una "substancia media entre lo vegetal y lo animal" que ofrecía grandes beneficios para el ser humano. Luego de resaltada la importancia de tal nutriente, como buen médico higienista daba una serie de prescripciones detalladas sobre el inicio y el fin del período de lactancia, la regularidad con la que se debe amamantar al niño, advirtiendo que no era recomendable tenerlos sin mamar muchas horas. Si bien no estaba completamente de acuerdo con el empleo de amas de leche, establecía una serie de condiciones indispensables que debía cumplir la mujer que, por distintos motivos, se encargase de alimentar al bebé.

"Si le ha de criar alguna nutriz a la que llamamos ama, elíjase esta de edad de 25 a 30 años, sana, que tenga la cutis limpia, de una índole tranquila, y de las mejores costumbres: que su leche sea abundante, blanca, sin olor, que el gusto no sea salado sino

73 Ejemplos de anuncios aparecidos en el Diario de Lima en 1791 son: "venta de una mulatilla de 17 años preñada" ( 3 de enero), "venta de dos criadas, una para ama de leche y otra para jornal" ( 6 de enero), "venta de negra bozal parida con su cría" ( 9 de enero) o "venta de ama de leche" (12 de enero).

74 Forns, Roberto: La Estrategia Comunicativa...

75 Zegarra: "La construcción de la madre...", págs. 195-199.

76 Unanue, Hipólito: El Clima de Lima y su influencia en los seres organizados, en especial el hombre, Imprenta de los Huérfanos, Lima, 1812, pág. 144. 
dulce, que la leche sea delgada, que se diluya fácilmente en el agua, y que echada una gota en el ojo no le lastime". ${ }^{77}$

Por su parte, en una disertación sobre las causas de la decadencia de la vida humana, el doctor Pedro Nolasco Crespo consideraba que un motivo fundamental de los problemas de salud era la falta de la lactancia materna en la infancia o el breve período de lactación del infante. Con argumentos históricos y médicos se buscaba persuadir a las madres de lo necesario que era cumplir con esa función natural. La robustez, sinónimo de salud, y la longevidad del hombre iban en relación con el tiempo que duraba la lactancia materna. ${ }^{78}$ El tratamiento del tema por parte de Hipólito Unanue y Nolasco Crespo nos muestra cómo algunos de los médicos terminaron por aceptar como necesario el hecho de recurrir a las amas de leche, punto de vista que se manifiesta también en los escritos del Mercurio Peruano, muchos de cuyos redactores pertenecían a la elite limeña. En tal sentido se mostró contrario a la postura crítica asumida por Olavarrieta en el Semanario, debido a su formación española y su estadía corta en el país. Sin embargo, no se produjo una aceptación total de la práctica, pues, con regularidad, se expresaron los problemas y efectos negativos que acarreaba, sobretodo en el plano cultural y familiar.

Como las negras esclavas y mujeres de las castas eran las que cumplían el rol de amas de leche y se dedicaban a la crianza del niño, ${ }^{79}$ una de las principales razones esgrimidas para erradicar esta práctica era que a través de la leche, estas mujeres transmitían las enfermedades y los vicios propios de su raza; ${ }^{80}$ creencia que se remontaba al siglo XVI en el Perú. ${ }^{81}$ Al lado de este poderoso argumento, Olavarrieta desenvainó en su argumentación otros de carácter histórico, higienista, moral o religioso, a los que pasaremos revista rápidamente por haberse tratado ya en otros trabajos. En cuanto a la referencia histórica, afirmaba que este hábito no tenía parangón con ningún otro de la antiguiedad, ni de las naciones cultas o los pueblos más salvajes. ${ }^{82}$ Con respecto a la higiene, apoyándose en Buffon, el editor del

77 Unanue: El Clima de Lima..., pág. 147.

78 Nolasco Crespo, Pedro: "Conjeturas sobre las causas de la decadencia de la vida humana", 14 de agosto de 1791, Mercurio Peruano, t. II, págs. 278-285.

79 El conjunto de las amas de leche estaba constituido tanto por esclavas domésticas, compradas o alquiladas, como por mujeres de diversas castas de la plebe urbana que recibían una remuneración.

80 Olavarrieta: Semanario Crítico, N..$^{\circ} 6 \ldots$

81 Lavallé: Las Promesas ambiguas..., pág. 48.

82 Olavarrieta: Semanario Crítico, N. $^{\circ} 3 \ldots$ 
Semanario sostenía que podía causar enfermedades y hasta la muerte de la criatura.$^{83}$ En todo momento se ataca el descuido y el olvido del niño por parte de la madre; sin embargo, hay que considerar lo afirmado por Linda Pollock quien señala que la persistencia de esta práctica se debió más a la inercia de una costumbre social que al descuido hacia los bebés ${ }^{84} \mathrm{Da}$ la impresión de que para explicar este fenómeno los estudiosos se apropiaron del discurso ilustrado del XVIII relegando al olvido que el amor maternal es también una construcción cultural.

Asimismo, buscando conmover a las mujeres Olavarrieta sostenía que el amor materno, fundado en Dios y la naturaleza, podía hacer que las madres se encargasen de sus hijos. ${ }^{85}$ Es decir, amamantar al hijo y criarlo era un deber "natural" que debían cumplir las mujeres para ser madres en todo el sentido de la palabra, y cumplir dicho deber era posible gracias al amor maternal. Olavarrieta describía con detalle todas las responsabilidades de la madre desde el cambio de pañales y la limpieza del bebé hasta la renuncia al sueño y a la diversión por dar de lactar, enfatizando que "son trabajos cuyo sufrimiento exige sin la menor duda una virtud heroica, una paciencia consumada, ó los estimulos de un amor excesivo, y vehemente". De esta manera, aparecía en el discurso el gran argumento ilustrado e higienista, sobre la base del cual se construía la familia ilustrada, el amor de las madres. Justamente a ellas dirigirá sus más duras palabras el sacerdote, quien les imputará la responsabilidad de esta situación por preferir dar los hijos a una extraña debido al motivo frívolo de preservar su belleza para agradar a su marido. ${ }^{86} \mathrm{Al}$ lado de estos argumentos — naturaleza, higiene, utilidad - que se revelaban caros a la Ilustración, estaba otro de los grandes temas: la educación. Así, se vio como altamente nociva la participación de negras y mulatas en la educación de los niños dado que por sus creencias y costumbres ponían al niño gran cantidad de ropa; lo asustaban con el "coco" y le contaban historias de duendes, diablos y brujas; y por su forma de hablar, influían negativamente en su aprendizaje del idioma. ${ }^{87}$

La polémica en torno de la lactancia materna y las amas de leche reflejaba el desarrollo de una serie de procesos que no solamente tenía que

83 Olavarrieta: Semanario Crítico, N. $^{\circ} 6$...

84 Pollock, Linda: Los niños olvidados. Relaciones entre padres e hijos de 1500 a 1900, FCE, México, 1990, págs. 249-252.

85 Olavarrieta: Semanario Crítico, N. ${ }^{\circ} 9 \ldots$

86 Olavarrieta: Semanario Crítico, N. ${ }^{\circ} 7$...

87 Olavarrieta: Semanario Crítico, N. ${ }^{\circ} 2 \ldots$ 
ver con la construcción de un nuevo modelo de familia, sino también de sociedad. En Europa el progresivo avance de la lactancia materna - como acertadamente menciona Mónica Bolufer- significó la deslegitimación de formas de vida aristocráticas, en favor de los ideales burgueses de sociedad que buscaban la emulación de la familia y el espacio privado. ${ }^{88}$ Por ello, Olavarrieta veía el hecho de recurrir a las amas de leche como un uso aristocrático, explicado por las distinciones y lujos de que debía gozar la nobleza. En este sentido, como afirma Georges Vigarello, los nuevos valores higiénicos se opusieron al viejo ideal aristocrático: el reforzamiento de la descendencia contra el prestigio del linaje. En un momento en que la burguesia buscaba reforzar las generaciones futuras, los nuevos valores sanitarios se enfrentaron a los valores tradicionales de la sangre: la certeza de la posteridad contra la certeza de la ascendencia. ${ }^{89}$ De tal manera, la leche comenzó a reemplazar a la sangre como símbolo emblemático de los nuevos ideales de vida burgueses. Si bien en Europa ese proceso fue más evidente, en el Perú presentó más problemas y contradicciones debido a la fuerte estratificación social y la expansión de la aristocracia en el siglo XVIII. De todas formas, al redefinir la relación madre-hijo, el discurso sobre la lactancia materna colaboró en la construcción de un nuevotipo de familia, como lugar de los afectos y con roles claramente diferenciados para el hombre y la mujer. La familia sentimental, tal cual la conocemos hoy en día al menos en Occidente, es un producto de la redefinición de esa praxis familiar del siglo XVIII. ${ }^{90}$

\section{La educación de los hijos en el hogar}

La familia como espacio privado centrado en padres e hijos se empieza a diferenciar, entonces, del ámbito público, del cual la mujer será finalmente excluida. El periódico que más claramente explicitó esta exclusión de la mujer del espacio público y, por ende, de la política fue, sin

88 Bolufer: Mujeres e Ilustración...

89 Vigarello, Georges: Histoire des pratiques de santé. Le sain et le malsain depuis le Moyen Age, Editios du Seuil, Paris, 1999, pág. 162.

90 Sobre el desarrollo de la familia en Europa véase Flandrin, Jean-Louis: Los orígenes de la familia moderna, Crítica, Barcelona, 1979. Aries, Philippe: Padri e figli nell'Europa medievale $e$ moderna, Laterza, Roma, 1999. Stone, Lawrence: Familia, sexo y matrimonio en Inglaterra, 15001800, FCE, México, 1990. Para una crítica del concepto de familia sentimental es interesante el enfoque de Goody, Jack: La famiglia nella storia europea, Laterza, Roma, 2000. 
lugar a dudas, la Gaceta de Lima, que terminó por encerrar a las mujeres en la casa argumentando que "no tienen la fuerza moral ni física que exige el ejercicio de los derechos políticos del ciudadano" y que si se dedicasen a cumplir estas funciones, "tendrían que sacrificar por ellas los cuidados más importantes a que las llama la naturaleza". Además, "las mujeres por su organización son propensas a una exaltación que sería funesta en el examen de los negocios públicos". ${ }^{91}$ Se estaba produciendo una feminización del espacio privado a la par que la masculinización del espacio público. Por eso, los recurrentes artículos, sobretodo en el Mercurio, en que se reprobaba a las mujeres su agitada vida social en los lugares públicos y se las conminaba a volver a la casa. En este mismo sentido se dirigían las críticas a la mujer gastadora, que según las quejas de un airado esposo en el Mercurio gastaba excesivamente en su vestuario, especialmente en el de tapada. ${ }^{92}$ El problema que se ponía en evidencia no sólo era el del lujo de las mujeres y el excesivo gasto que éste significaba para la economía familiar, sino también el nuevo ideal de mujer laboriosa, recatada y dedicada completamente al hogar que se buscaba. Así, otro esposo se quejaba en el Diario de haber sido engañado mediante los artificios de la cosmética, pues descubrió que la belleza de su esposa "era un puro efecto del arte". ${ }^{93}$ El nuevo modelo de feminidad iba de la mano con una nueva estética de simplicidad, formas delgadas y rostro natural, pálido, sin maquillaje.

El discurso ilustrado e higienista presentaba una nueva feminidad en todos los sentidos y la mujer debía cumplir su rol natural en el hogar. La educación debía estar en manos de las madres, que no podían desembarazarse de esta importante responsabilidad dejándola en manos de las nodrizas. En un extenso artículo aparecido en sucesivos ejemplares del Diario de Lima se reprobaba la moralidad de las mulatas y negras que eran mujeres "corrompidas y llenas de vicios" a las que los padres no debían encargar la educación de sus hijos. ${ }^{94}$ Del mismo modo se expresaba el Mercurio presentando los daños que estas mujeres ocasionaban en la educación a tra-

91 Durand (Ed.): Gaceta de Lima..., N. ํ 22, 11 de junio de 1794, pág. 299.

92 Fixiogamio: "Carta escrita a la sociedad sobre los gastos excesivos de una tapada", 10 de febrero de 1791, Mercurio Peruano, t. I., págs. 111-114.

93 "A las mujeres que se afeitan" en Cabello (Ed.): Diario de Lima, 17 de febrero de 1791.

94 Cabello y Mesa: "Reflexiones crítico-físicas y económicas por la que se demuestran los perjuicios que se originaron en el Perú con la introducción de los negros", en Cabello (Ed.): Diario de Lima, 9 al 15 abril de 1791. 
vés de un caso edificante, en el que nuevamente un furibundo esposo se lamentaba al ver trastocada completamente las jerarquías y roles al interior de su hogar. ${ }^{95}$ Entonces, no había otra salida, la mujer debía preocuparse más por sus hijos que por su belleza y su vida pública, debía educarlos en el hogar y debía tener una participación activa en la reforma del ámbito doméstico. Al deber ser la mujer esencialmente madre, el Diario criticó la educación conventual por considerarla contraria a la naturaleza. La educación, y sobre todo aquella de las hijas, debía estar bajo la responsabilidad de la madre, quien debía ser el ejemplo de las virtudes femeninas y el modelo a seguir. ${ }^{96}$ Sin embargo, esta formación debía tener como centro el hogar, por lo que se propagandizaba la educación en la casa en contra de aquella que se daba en los conventos. En la época del triunfo del espacio abierto y el aire libre, los monasterios eran vistos como "cavernas tenebrosas" donde las niñas estaban recluidas, lo que acarreaba malas consecuencias para su salud y constitución. ${ }^{97}$

La buena educación era un aspecto tan vital que la homosexualidad era atribuida a los defectos de la educación materna en los primeros años. La afeminación de los "maricones" — considerados tan raros como los monstruos, enanos o hermafroditas- era causada por "una viciosa educación", con un excesivo amor materno, que orientaba al niño, desde muy pequeño, al realizar tareas delicadas. Se concluye, de modo lapidario, afirmando que con una buena educación se verían menos costumbres afeminadas y habrían menos maricones..$^{98} \mathrm{La}$ influencia que detentaba la madre sobre los hijos era en esos momentos bastante grande y los ilustrados se dirigían a ella para tutelar su conducción de la familia.

95 Eustaquio Filomates [Rossi y Rubí, José]: "Amas de leche. Segunda carta de Filomates sobre la Educación”, 27 de enero de 1791, Mercurio Peruano, t. I, págs. 59-62. También véase como ejemplo Hesperióphylo [Rossi y Rubí, José]: “Amas de leche”, 23 de enero de 1791, Mercurio Peruano, t. I, págs. 59-62.

96 "Cuanto importa la buena educación de las doncellas" en Cabello (Ed.): Diario de Lima, 17 y 22 de diciembre de 1791 y "La crianza mujeril al uso. Octavas"en Cabello (Ed.): Diario de Lima, 10 de enero de 1791 .

97 "Inconvenientes que resultan de encerrar a las señoritas en los conventos cuando están próximas a la pubertad" en Cabello (Ed.): Diario de Lima, 11 de enero de 1791.

98 Tanto en el Mercurio Peruano como en el Semanario Crítico hay artículos en los que se atribuye la homosexualidad a los defectos de la crianza materna. Olavarrieta: Semanario Crítico, N. ${ }^{\circ}$ 5; Filaleltes: "Carta sobre los maricones", 27 de noviembre de 1791, Mercurio Peruano, t. III, págs. 230232; Teagnes: "Carta remitida a la Sociedad haciendo algunas reflexiones sobre la que se contiene en el Mercurio Num. 94 en que se pinta a los maricones”, 19 de febrero de 1792, Mercurio Peruano, t. IV, págs. 118-122. 


\section{Hacia un nuevo modelo de madre en la familia}

En el siglo XVIII, a partir de la visión ilustrada del mundo, los intelectuales y hombres de ciencia elaboraron un nuevo modelo de feminidad esencialista en donde la mujer es vista como una categoría atemporal y universal. Ellos reencontraron en una parte misteriosa de su cuerpo, el útero, la verdadera identidad femenina y con el prestigio que les daba su arte no sólo les explicaron cómo eran sus cuerpos y cómo funcionaban sus íntimos y secretos procesos, sino también, les enseñaron con sapienza cómo debían comportarse, qué debían sentir y hasta cómo debían vivir. El discurso médico, tributario de un orden del mundo que era necesario legitimar, mostraba que el rol de cada sexo estaba instituido en la naturaleza y, en ese sentido, la vocación natural de la mujer era la maternidad. Con sesudas pero didácticas disquisiciones, presentando casos que tenían más la fuerza de la edificación que el rigor científico, apelando tanto a la razón como a los sentimientos, generando controversia y debate; médicos e intelectuales se dirigieron a las mujeres con afán pedagógico y docente para decirles cómo debían ser madres, pues consideraban que todas las mujeres podían dar a luz, mas no todas podían ser verdaderamente madres. Entonces, desplegaron todo un discurso higienista en donde les hablaron del embarazo y el parto, la prevención del aborto, la cesárea, la importancia de la educación de los hijos, la lactancia, entre otros temas. Todo ello orientado a una pedagogía de la madre ilustrada, que tenía la misión de configurar a la familia, quintaesencia de la moderna sociedad burguesa, como espacio privado y lugar de los afectos. Sin embargo, este proceso de construcción de la maternidad y la familia en el Perú no fue ajeno a las ambivalencias y contradicciones propias de una sociedad jerarquizada y con grandes diferencias sociales, cuya transición a la modernidad fue lenta y difícil. 